\title{
ПСИХОЛОГІЧНІ ЧИННИКИ, ЩО ВПЛИВАЮТЬ НА УСПІШНІСТЬ ШЛЮБУ
}

УдК: 159.9:316.6

\section{Проскурняк Ольга Петрівна}

Кандидат психологічних наук, доцент кафедри психології Чернівецького наиіонального університету імені Юрія Федьковича, м. Чернівиі (Украӥна)

\section{Папуиак Наталія Любомирівна}

Магістр факультету психології Чернівецького національного університету імені Юрія Федьковича, м. Чернівиі (Україна)

\begin{abstract}
Анотація. Стаття присвячена дослідженню сутнісних характеристик понять «задоволеність подружнім життям» та «успішність і стабільність шлюбу». Подано стислий огляд проблеми, описано феноменологію категорії у наукових дослідженнях, викладено теоретичні та методологічні підходи щодо вивчення чинників успішності шлюбу в цілому.

Встановлено, щуо чинниками успішності илюбу є психологічна сумісність партнерів, відповідність їх рольовим очікуванням, сочіально-психологічний клімат у сім'ї. Успішні сімейні стосунки формуються при взаємній задоволеності подружжя, їх відповідності один одному в різноманітних видах і сферах взаємодії всередині сім'ї та поза нею.
\end{abstract}

Ключові слова: шлюб, задоволеність подружнім життям, успішність $i$ стабільність шлюбу.

Постановка проблеми. Соціо- при різкому зниженні важливості шлюбу як культурні й економічні трансформації, що відбуваються Україні, впливають й на приватну сферу життя людини, іiї сім'ю. Родина розглядається як посередник між особистим і громадським життям, а інститут шлюбу вважається базовим для підтримки суспільної системи. Одним із протиріч соціального інституту.

Дослідження сім’ї відбивають кризовий стан інституту шлюбу, проявами якого $\epsilon$ негативні показники відтворення населення, зниження кількості зареєстрованих шлюбів, висока частота позашлюбних стосунків, постійне зростання кількості сучасної української родини є підвищення іiі значимості для кожного конкретного індивіда розлучень та неповних сімей, підвищення популярності «альтернативних» форм шлюбу 
(гомосексуального, відкритого, сім’ї-сінгл, дистантного шлюбу тощо), збільшення терпимості до різноманітних варіантів неосексуальних практик. Ученими фіксується також зниження якості сімейних стосунків та задоволеності шлюбом, погіршення адаптивних можливостей сім’ї, зростання ii дисфункційності [9].

Мета роботи - виявити та проаналізувати основні чинники впливу на формування успішного шлюбу.

Аналіз літератури

проблеми дослідження показав, що при аналізі задоволеності подружжя шлюбом слід звернутися до аналізу таких понять як соціальнопсихологічний клімат сім'ї, сумісність, стабільність та стійкість подружніх стосунків. До проблеми подружньої сумісності в плані особистісних характеристик, a також рольових i ціннісних орієнтацій подружжя зверталися в своїх дослідженнях А. Н. Волкова, А. К. Дмитренко, Т. В. Галкіна, Д. В. Ольшанський, А. П. Ощепкова, Б. М. Пєтухов, К. Вітек, Д. Майерс та інші. Великий блок робіт присвячено проблемі орієнтацій подружжя в сфері сімейних ролей, зокрема, Н. Н. Обозова, Н. Ф. Федотова, В. В. Матина, С. В. Антонюк. На необхідність врахування в дослідженнях змін, що відбуваються в сім’і на різних стадіях ii існування, вказують Ю. Є. Альошина, О. М. Волкова, Т. М. Мішина,
Т. А. Гурко та інші. Дослідження останніх років продовжують розкривати особливості ціннісних орієнтацій і уявлень про сім'ю і шлюб у людей, які вже створили сім'ю, або готуються до цього (В. С. Торохтій., Е. Г. Ейдеміллер, В. В. Юстицкис, В. М. Дружинін, Н. Л. Москвичова, Р. Г. Гурова та інші). Варто також відзначити, що у різні часи автори (А. Адлер; В. А. Сисенко, Т. В. Андрєєва, А. Н. Харитонов, Г. Н. Тимченко) вказували на роль зрілості особистості як чинника успішності ㄲï шлюбу. Питання сумісності подружжя в різних сферах висвітлюються у працях А. Н. Волкова, М. М. Обозова, Е. М. Тійт, Т. М. Трапезнікової, S. J. Bahr, C. B. Chappel, G. K.Leigt, R. B. Schafer та інші. Виклад основного матеріалу. У працях А. Ю. Тавіт була представлена одна 3 перших та найбільш змістовних класифікацій чинників задоволеності шлюбом, у якій автор виокремлює дві групи таких чинників: ті, які виникли до вкладання шлюбу, та ті, що з'явилися під час шлюбного періоду. На думку А. Ю. Тавіт, перша група чинників є психологічною основою шлюбу. Вона поєднує такі аспекти, як походження (дещо схожого на поняття «сімейного сценарію» за Е.Берном), якості особистості, мотиви вступу до шлюбу. Друга група складається з етичноемоційних стосунків подружжя, психофізіологічних взаємостосунків подружжя, єдності поглядів на виховання 
дітей, на розподіл домашніх та господарських обов'язків, вільний час та його проводження, стосунки із батьками подружжя, друзями [19].

Успішність шлюбу - це комплексний інтегральний показник, що містить оцінку шлюбних стосунків 3 точки зору: а) суспільства й залучення родини до соціальної системи (соціальна складова); б) гармонійної та функціональної життєдіяльності родини в процесі іiі становлення й розвитку (сімейносистемна складова); в) найбільш повного розкриття особистісного потенціалу кожного 3 подружжя, установлення між ними зрілої міжособистісної комунікації (екзистенціально-гуманістична складова) [4].

У першому випадку аналізується виконання родиною основних соціальних функцій (репродуктивної і виховної) та ступінь стабільності шлюбу, в другому й третьому - розглядається задоволеність кожного 3 подружжя спільним життям i наявність у родині умов для гармонійного розвитку особистості подружжя й дітей. Сімейно-системна та екзистенційногуманістична компоненти, власне, і $\epsilon$ психологічними сторонами процесів функціонування шлюбної системи, що лежать в основі її успішності.

Можна виділити кілька основних підходів до вивчення проблеми стабільності шлюбу. У низці робіт аналізуються соціально-психологічні макропроцеси, які впливають на загальне зниження значущості шлюбу як соціального інституту: урбанізація, міграція населення, ослаблення контролю за поведінкою окремого індивіда 3 боку референтної групи, анонімність міського стилю життя, ослаблення зовнішнього впливу норм і традицій, зростання соціальної активності жінок, посилення потреби в егалітаризації подружніх стосунків, яка часто залишається незадоволеною $[1,5,7,17]$.

Ряд теорій, що аналізують механізми стабільності й стійкості шлюбу, визначають їх як «стійкість міжособистісних стосунків у подружжі» [2]. Під стабільним розуміється шлюб, у якому обидва партнери задоволені спільним життям; стійкість шлюбу - це збереження його (на противагу розпаду). Стабільність шлюбу розглядається через призму задоволення / незадоволення потреб подружжя, серед яких жінки у ролі базових виділяють потребу «в емоційному теплі», у відчутті цінності й важливості своєї особистості, у взаємодопомозі та взаємній підтримці [23].

С. І. Голод [6] виділяе три цінності (адаптованість, інтимність, автономія), властиві шлюбам із високим показником подружньої задоволеності. Як гомеостабілізуючі розглядаються адаптаційні процеси в психологічній, сексуальній i духовній сферах та інтимність, яка містить у собі симпатію (домінанта у стосунках), приязнь, вдячність і еротичну прихильність. Механізмом розвитку й трансформації 
шлюбних стосунків є подружня автономія, яка виражається в тому, що інтереси подружніх партнерів ширші за сімейні, а потреби й коло спілкування кожного 3 них виходять за межі шлюбу.

Спостерігається зв'язок між успішністю шлюбу та віком, у якому жінка вийшла заміж: дослідники [3] відзначають неміцність ранніх шлюбів. Крім того, у подружжях, які перебувають «напередодні розлучення», значно більше осіб, які взяли шлюб у віці до 21 року, ніж у групі успішних родин [3]. Найміцніший зв'язок між раннім віком одруження й незадоволеністю шлюбом спостерігається в молодих жінок, оскільки вони тяжко переживають невідповідність власних романтичних уявлень щодо сімейного життя та реальності (в їх уяві шлюб асоціюється насамперед із любовними переживаннями, тоді як у дійсності вони стикаються з необхідністю виконувати певні буденні обов'язки) [9].

Національність і релігійні переконання також впливають на стабільність шлюбу: національні традиції й норми у сфері шлюбно-сімейних стосунків, релігійні переконання подружжя пов'язані 3 рівнем розлучень. Водночас окремі дослідники простежують зв'язок зазначених параметрів із задоволеністю жінки шлюбом, зазначаючи, що найбільше значення має, очевидно, соціокультурний контекст і відповідність реальних подружніх стосунків рольовим настановам жінки [16].

Т. В. Андрєєва і Г. Навайтіс показали, що найбільш стійкими є родини з однаковим рівнем освіти обох членів подружжя; тоді як найменш стійкі ті, де освіта дружини перевищує рівень освіти чоловіка [3, 15]. Дослідники пов'язують це 3 тим, що високоосвічені жінки пред'являють вищі вимоги до чоловіка 3 точки зору рівня духовного спілкування, змістовного дозвілля, характеру стосунків у родині. Вони частіше відстоюють егалітарну модель сімейних стосунків, що не завжди відповідає очікуванням чоловіків [8].

Окреме місце у дослідженні стійкості шлюбу посідають соціально-демографічні параметри. Гомогенні, з погляду соціальної належності подружжя, шлюби більш стабільні; розлучаються найчастіше гетерогенні за своїм соціальним статусом подружні пари [16]. Така закономірність, очевидно, зумовлюється відмінністю ціннісних орієнтацій, настанов, уявлень щодо подружніх ролей в осіб, які належать до різних соціальних верств. Суперечки між партнерами в гетерогенних шлюбах нерідко посилюються тим, що кожен з них підтримує стосунки 3 друзями й родичами, які в таких випадках, зазвичай, відрізняються системами ціннісних і духовних потреб [11].

У вітчизняній літературі представлено дані, згідно 3 якими менш стабільними $є$ шлюби, в яких чоловік має сільське 
походження, а дружина - міське [16]. У цих випадках, очевидно, відбувається зіткнення різних сімейних культур, причому чоловік не поступається вимогам дружини при поділі сімейних ролей. У протилежному випадку можливість виникнення таких конфліктів менш імовірна: дружина, орієнтована на родину традиційного типу, може або реалізувати свої очікування, або, опинившись у більш демократичному середовищі, пристосуватися до нього. Крім того, мешканці сільської місцевості частіше діють відповідно до батьківських норм, у той час як мешканці міста більше схильні орієнтуватися на референтну групу, де розлучення вважається припустимим.

Всупереч поширеній думці, економічні чинники мало пов'язані зі стабільністю родини. Як правило, набагато більшу роль відіграє не статок як такий, а різниця в уявленнях чоловіка й дружини (а також їх родичів і референтної групи) щодо того, яким має бути бюджет родини i як його розподіляти [3]. 3 іншого боку, підвищення стандартів життя й активна пропаганда цінностей «суспільства споживання» ускладнюють прийняття рішення щодо створення родини. Потенційні шлюбні партнери мають різну власність, а тому підвищилася економічна роль шлюбу, ставлення до нього стало більш прагматичним, хоча шлюбні контракти не одержали широкого поширення через невідповідність соціокультурному контексту. У цілому ж для стабільності шлюбу й тривалого спільного життя подружжя більш значущими є орієнтації на родину як таку, а не на любовні стосунки в шлюбі. Кохання, якщо розуміти його в сенсі емоційної й фізичної привабливості одне для одного, а не довгострокового й сталого почуття, не $є$ гарантією успішності шлюбних стосунків, тим більше, що найбільш поширена в культурі норма «романтичної любові» за своєю сутністю може вважатися варіантом міжособистісної залежності [12]. Зокрема, опитування подружжів перед розлученнями показують, що більшість 3 тих, хто одружувався «через кохання», називає причиною розлучення «втрату почуттів». У ряді випадків (особливо в ранніх шлюбах) фіксуються когнітивна простота, спрощення уявлень подружжя щодо шлюбу, одне про одного, завищені рольові очікування [17].

Крім того, шлюби, що привели до розлучення, найчастіше створені за вимушеними обставинами (під тиском соціальних норм) або $є$ відбиттям особистісної незрілості подружжя. Серед таких причин можна назвати: вагітність, прагнення покинути рідний дім, бажання поліпшити своє матеріальне становище. Важливим, хоча i дещо суперечливим, чинником зниження задоволеності шлюбом $€$ стосунки 3 батьківською родиною. 3 одного боку, спільне проживання з батьками чоловіка 
або жінки стає причиною конфліктів подружжя; 3 іншого - молоді родини виявляються дещо стабільнішими в умовах спільного проживання разом 3 батьками одного з подружжя. Водночас проживання із представниками старшого покоління оцінюється подружжям як вимушений крок, хоча допомога у вихованні онуків уважається важливою культурною складовою родинних взаємин [17].

На тлі підвищення цінностей автономії й незалежності, формування розбіжностей поколінь у життєвих ідеалах, настановах і пріоритетах змінилися стосунки між батьками й дорослими дітьми [17]. Якщо раніше матеріальна допомога батьків дорослим дітям часто здійснювалася «в обмін» на втручання в їх особисте життя, то зараз діти прагнуть жити окремо від батьків та намагаються уникати вступу до офіційного шлюбу до досягнення власної економічної незалежності. Отже, відділення від батьків стає важливою умовою створення власної родини.

Вступаючи до шлюбу, молоді люди 3 дисфункційних родин найчастіше виявляються не готовими до спільного життя, тому що не мають позитивного зразка сімейних взаємин i в найкращому разі усвідомлюють, «як робити не потрібно» [13]. Інший аспект впливу батьківської родини умови, у яких відбувалося дитинство особи, й наявність сиблінгів [3]. Як відзначає
В. В. Сисенко [18], труднощі при вступі до шлюбу можуть відчувати люди, які були єдиними дітьми. Виявлено також, що дружини, які були єдиною дитиною в родині, і чоловіки, які виховувалися без сестер, більше схильні до розлучення.

Ставлення батьків до рішення дітей щодо вступу до шлюбу також $є$ значущим чинником, що впливає на розвиток стосунків у родині. Опитування подружжів, які розлучаються, демонструють, що значна частина їх одружувалася, або не повідомивши батьків узагалі, або всупереч батьків хоча 63 однієї сторони. У неуспішних родинах батьки подружжя 3 осудом ставилися до шлюбу своїх дітей у кілька разів частіше, ніж в успішних (це однаково стосується й чоловіків, і жінок) [11]. Опитування свідчать, що від 33,5 до 46 \% пар, які розлучаються, на момент одруження були знайомі менше 6 місяців. Період, протягом якого майбутні партнери вивчають одне одного, набуває особливого значення в умовах, коли стосунки в шлюбі засновані не стільки на закріплених ролях чоловіка й дружини, скільки на особистісних особливостях шлюбних партнерів [2]. Ряд авторів указує, що шлюби, укладені після дуже тривалого знайомства, також не відрізняються стійкістю у зв'язку зі зниженням емоційності у стосунках на момент створення сім'ї [12].

Дошлюбні сексуальні стосунки не $\epsilon$ чинником, який суттєво впливає на 
стабільність шлюбу. Водночас, чинником високого ризику для успішності майбутнього шлюбу є дошлюбна вагітність, оскільки вона скорочує період залицяння й узгодження майбутніх моделей подружньої взаємодії. Такі шлюби часто укладаються без любові та 3 невідповідним партнером; у разі відсутності підтримки батьків вони неспроможні економічно. Крім того, чоловік незадоволений тиском сімейних обов'язків, дружина страждає від навантаження по догляду за дитиною й приділяє менше уваги емоційній стороні взаємин із чоловіком [3].

Однією із спроб систематизувати отримані у різних дослідженнях чинники задоволеності шлюбом можна назвати виділені Т. А. Гурко такі чотири групи чинників: 1. Соціально-демографічні та економічні характеристики сім'ї: величина сукупного сімейного доходу, вік подружжя, кількість дітей у сім’ї тощо. 2. Характеристики позасімейної сфери життєдіяльності подружжя: професійна сфера, взаємодія подружжя 3 найближчим соціальним оточенням тощо. 3. Установки та поведінка подружжя в основних сферах сімейної життедіяльності: розподіл господарсько-побутових обов'язків та збіг установок у цій сфері сімейного життя, організація дозвілля. 4. Характеристики подружніх стосунків: емоційно-моральні цінності (почуття кохання та поваги до партнера, спільні погляди та інтереси, подружня вірність тощо) [7].

Крім того, висновок про вплив тієї або іншої причини вірний лише як тенденція; у реальній життєдіяльності родини такий вплив опосередковується дією інших чинників. I якщо, наприклад, розбіжність репродуктивних настанов чоловіка й дружини в середньому негативно позначається на успішності шлюбу, то для подружжя, у системі цінностей яких діти не посідають перших місць, цей факт може не мати ніякого значення [12].

Coleman M. наводить низку критеріїв, за якими можна визначити потенційні джерела проблем і конфліктів у подружніх парах та сфери порушення подружньої взаємодії: 1) статусні диспозиції в родині; 2) система правил поведінки в родині (у т.ч. обов'язковість дотримання в родині встановленого порядку й толерантність до проявів поведінки, що відхиляється); 3) індекс індивідуалізму; 4) співвідношення принципів близькості та відокремлення; 5) рівень припустимої незалежності; 6) особистісна відповідальність, ставлення до прав i обов'язків; 7) особистісна автономія (просторова; емоційна; матеріальна); 8) індекс маскулінності в родині (поширеність дій членів родини з надання взаємної підтримки, захисту й допомоги, тобто визначається рівень корпоративності сімейної групи). Водночас, індекс маскулінності дозволяе виявити частоту використання чоловіками силових методів вирішення внутрісімейних проблем. 
Отже, міжособистісні стосунки в шлюбі мають певне гендерне забарвлення, що свідчить про різницю «чоловічих» $\mathrm{i}$ «жіночих» потреб у родині [21].

Найбільш сензитивними з точки зору зниження успішності шлюбу є:

сфера «оцінки особистісних якостей»дружини досить низько оцінюють власних чоловіків, відзначаючи наявність проблем із алкоголем, емоційну нечутливість, ревнощі, ненадійність [18];

сфера «розв'язання конфліктів у подружжі» - i жінки, і чоловіки відзначають відсутність умінь ефективно вирішувати конфлікти в шлюбі; дружини також говорять про уникання чоловіками конфліктних ситуацій [13];

сфера «спілкування» - чоловіки частіше незадоволені вмінням дружин їх слухати, а дружини відзначають нездатність чоловіків виражати свої думки й почуття [12].

Водночас легітимною для українських родин продовжує залишатися модель «стерпиться - полюбиться», яка означає, що підтримка шлюбних стосунків $є$ самоціллю, незалежно від психологічного стану подружжя й інших членів родини. Основними причинами, за якими шлюбні партнери продовжують підтримувати дисфункційний шлюб, є «відповідальність» за родину й дітей; релігійні заборони; надія на поліпшення взаємин; небажання визнати, що шлюб не вдався, оскільки для багатьох це є синонімом життєвого краху [20]. Основною причиною як у чоловіка так i жінки залишається побоювання залишитися поза шлюбом, який пов'язаний 3 вираженою психологічною залежністю, особистісною незрілістю й низькою самооцінкою. Для порівняння можна навести причини, за якими прагнуть зберегти шлюб подружні пари, задоволені своїми стосунками: 1) чоловік (дружина) є кращим другом; 2) чоловік (дружина) подобається як особистість; 3) шлюб - це довгострокове зобов'язання; 4) шлюб є священним; 5) спільні цілі; 6) чоловік (дружина) згодом викликає все більшу цікавість; 7) бажання, щоб подружні стосунки розвивалися успішно [22]. Отже, подружні стосунки можна охарактеризувати як взаємовідносини двох людей протилежної статі, які добровільно обрали один одного для створення сім'ї та особистісного зростання кожного з них.

Висновки. Виокремлюють дві групи чинників успішності шлюбу: ті, які виникли до вкладання шлюбу, та ті, що з'явилися під час шлюбного періоду. Перша група чинників $€$ психологічною основою шлюбу. Вона поєднує такі аспекти, як походження та якості особистості, мотиви вступу до шлюбу. Друга група складається 3 етично-емоційних стосунків подружжя, психофізіологічних взаємостосунків подружжя, єдності поглядів на виховання дітей, на розподіл домашніх та господарських обов'язків, вільний час та його проведення, стосунки із батьками подружжя, 
друзями.

Водночас, аналіз робіт не дає змогу виявити специфіку трансформації поняття «задоволеність шлюбними стосунками» у зв'язку із сучасними змінами у функціонуванні інституту сім’і. Виявлення цих характеристик стане предметом нашого подальшого дослідження.

\section{Перелік використаних джерел:}

1. Aŭшnур $O$. C. Динамика структуры ценностей, ожидаемых и реализованных в браке, в соответствии с личностными особенностями супругов./О.С. Айшпур СПб: Изд-во СПбГУ, 2001. - 50 с.

2. Андреева T.B. Распределение ролей в молодой семье // Ананьевские чтения: психология и политика (Тезисы научно-практической конференции «Ананьевские чтения - 2002»). /Т.В. Андреева, А.В. Кононова - СПб., 2002. - С. 56-58.

3. Андреева T. В. Психология современной семьи: Учебное пособие. /Т.В. Андреева - СПб.: Речь. - 2005. - C. 111-212.

4. Антонюк $E . \quad B$. Становление ролевой структуры молодой семьи и ее восприятие супругами // Вестник МГУ. Серия 14: Психология. - 1993. - № 4. - С. 25-34.

5. Гармаев A. Психопатический круг в семье /A. Гармаев- Минск.: Лучи Софии, 2002. - 320 с.

6. Голод C. И. Моногамная семья: кризис или эволюция? // Психология семьи. Учебное пособие. / С.И. Голод - Самара, 2002. - С. 245-258.

7. Гурко T. A. Институт семьи в постиндустриальных обществах Ценности и смыслы. 2011. - № 4 (13). - С. 8 12.

8. Дубас М. К. Підготовка молоді до сімейного життя: гендерний вимір // Гендер: реалії та перспективи в українському суспільстві: Всеукраїнська науковопрактична конференція. Київ, 11-13 грудня 2003. /М.К.
Дубас - К, 2003. - С. 228-230.

9. Душкина $M . \quad P$. Психологическая андрогиния и внутрисемейные отношения // Семейная психология и семейная терапия. / М.Р. Душкина - 2003. - № 3. - С. 27-35.

10. Дымнова T. И. Зависимость характеристик супружеской семьи от родительской // Вопр. психологии. / Т.И. Дымнова - 1998. - № 2. - С. 46-56.

11. Клеции $A$. $A$. Внебрачные и альтернативные (немодальные) семьи: формы и содержание // Рубеж. 1994. - № 5. - C. 166-167.

12. Криченко E. В. Психологические аспекты качества семейно-брачных отношений // Приклад. психология. / Е.В. Криченко, В.А. Терехин - 1999. - № 5. - С. 63-74. 13. Медіна T. В. Трансформація гендерних ролей у сучасній сім'ї // Гендер: реалії та перспективи в українському суспільстві. Всеукраїнська науковопрактична конференція. - Київ, 11-13 грудня 2003. - К., 2003. - C. 64-65.

14. Минигалиева $M . \quad P$. Зрелые межличностные отношения: условия развития // Семейная психология и семейная терапия. / M.P. Минигалиева, Н.П. Ничипоренко - 2002. - № 1. - С. 31-35.

15. Навайтис $Г$. Семья в психологической консультации. / Г. Навайтис - М.: Изд-во МПСИ, 1999. $-224 \mathrm{c}$.

16. Овчарова $P$. В. Психологическое сопровождение родительства. Пособие / Р.В. Овчарова - М.: Институт Психотерапии, 2003. - 320 с.

17. Смелзер Н. Семья // Психология семьи. / Н. Смелзер - Самара, 2002. - C. 127-132.

18. Сысенко B. A. Брачно-семейная адаптация, её характер и содержание // Психология семьи. / В.А. Сысенко - Самара, 2002. - С. 547-575.

19. Тавит A. Ю. Факторы, влияющие на удовлетворенность браком // Личность в системе общественных отношений. / А.Ю. Тавит - Тарту: Тартусский гос.ун-т, 1984, - С.72-109.

20. Харчев А. Г. Семья как объект демографической политики // Актуальные вопросы семьи и воспитания. / 
А.Г. Харчев - Вильнюс, 1983. - С. 8-9.

21. Coleman M. Remarried Family Relationships /

M. Coleman, L. Ganong - NY, 1996. - 348 p.

22. Needle R. H., S. Su S., Doherty W.J. Divorce, Remarriage, and Adolescent Substance Use: A Prospective Longitudinal Study // Journal of Marriage and the Family. 1990. - Vol. 52. - No. 1. - P. 157-169.

23. Wallerstein J. S. The Unexpected Legacy of Divorce: A 25 Year Landmark Study / J.S. Wallerstein, J.M. Lewis. NY, 2000. - P. 248-265.

\section{References (Transliteration):}

1. Ajshpur O. S. Dinamika struktury cennostej, ozhidaemyh i realizovannyh $\mathrm{v}$ brake, $\mathrm{v}$ sootvetstvii $\mathrm{s}$ lichnostnymi osobennostjami suprugov./O.S. Ajshpur SPb: Izd-vo SPbGU, 2001. - $50 \mathrm{~s}$.

2. Andreeva T. V. Raspredelenie rolej v molodoj sem'e // Anan'evskie chtenija: psihologija i politika (Tezisy nauchno -prakticheskoj konferencii «Anan'evskie chtenija 2002»). /T.V. Andreeva, A.V. Kononova - SPb., 2002. - S. 56-58.

3. Andreeva T.V. Psihologija sovremennoj sem'i: Uchebnoe posobie. /T.V. Andreeva - SPb.: Rech'. - 2005. - S. 111212.

4. Antonjuk E. V. Stanovlenie rolevoj struktury molodoj sem'i i ee vosprijatie suprugami // Vestnik MGU. Serija 14: Psihologija. - 1993. - № 4. - S. 25-34.

5. Garmaev A. Psihopaticheskij krug v sem'e /A. GarmaevMinsk.: Luchi Sofii, $2002-320$ s.

6. Golod S.I. Monogamnaja sem'ja: krizis ili jevoljucija? // Psihologija sem'i. Uchebnoe posobie. /S.I. Golod - Samara, 2002. - S. 245-258.

7. Gurko T.A. Institut sem'i $\mathrm{v}$ postindustrial'nyh obshhestvah Cennosti i smysly. 2011. - № 4 (13). - S. 812.

8. Dubas M.K. Pidgotovka molodi do simejnogo zhyttja: gendernyj vymir // Gender: realii' ta perspektyvy v ukrai'ns'komu suspil'stvi: Vseukrai'ns'ka naukovo- praktychna konferencija. Kyi'v, 11-13 grudnja 2003. /M.K. Dubas - K, 2003. - S. 228-230.

9. Dushkina M. R. Psihologicheskaja androginija i vnutrisemejnye otnoshenija // Semejnaja psihologija i semejnaja terapija. / M.R. Dushkina - 2003. - № 3. - S. 2735 .

10. Dymnova T. I. Zavisimost' harakteristik supruzheskoj sem'i ot roditel'skoj // Vopr. psihologii. / T.I. Dymnova 1998. - № 2. - S. 46-56.

11. Klecin A. A. Vnebrachnye i al'ternativnye (nemodal'nye) sem'i: formy i soderzhanie // Rubezh. 1994. - № 5. - S. 166-167.

12. Krichenko E. V. Psihologicheskie aspekty kachestva semejno-brachnyh otnoshenij // Priklad. psihologija. / E.V. Krichenko, V.A. Terehin - 1999. - № 5. - S. 63-74.

13. Medina T. $V$. Transformacija gendernyh rolej $\mathrm{u}$ suchasnij sim'i' // Gender: realii' ta perspektyvy v ukrai'ns'komu suspil'stvi. Vseukrai'ns'ka naukovopraktychna konferencija. - Kyi'v, 11-13 grudnja 2003. - K., 2003. - S. 64-65.

14. Minigalieva $M . R$. Zrelye mezhlichnostnye otnoshenija: uslovija razvitija // Semejnaja psihologija i semejnaja terapija. / M.R. Minigalieva, N.P. Nichiporenko - 2002. - № 1. - S. 31-35.

15. Navajtis G. Sem'ja v psihologicheskoj konsul'tacii. / G. Navajtis - M.: Izd-vo MPSI, 1999. - 224 s.

16. Ovcharova $R$. $V$. Psihologicheskoe soprovozhdenie roditel'stva. Posobie / R.V. Ovcharova - M.: Institut Psihoterapii, 2003. - $320 \mathrm{~s}$.

17. Smelzer N. Sem'ja // Psihologija sem'i. / N. Smelzer Samara, 2002. - S. 127-132.

18. Sysenko $V$. A. Brachno-semejnaja adaptacija, ejo harakter i soderzhanie // Psihologija sem'i. / V.A. Sysenko - Samara, 2002. - S. 547-575.

19. Tavit A.Ju. Faktory, vlijajushhie na udovletvorennost' brakom // Lichnost' v sisteme obshhestvennyh otnoshenij. / A.Ju. Tavit — Tartu: Tartusskij gos.un-t, 1984, - S. 72109.

20. Harchev A. G. Sem'ja kak ob\#ekt demograficheskoj politiki // Aktual'nye voprosy sem'i i vospitanija. / A.G. 
Harchev - Vil'njus, 1983. - S. 8-9.

21. Coleman M. Remarried Family Relationships / M. Coleman, L. Ganong - NY, 1996. - 348 p.

22. Needle R.H., S. Su S., Doherty W.J. Divorce, Remarriage, and Adolescent Substance Use: A Prospective Longitudinal Study // Journal of Marriage and the Family. 1990. - Vol. 52. - No. 1. - P. 157-169.

23. Wallerstein J.S. The Unexpected Legacy of Divorce: A 25 Year Landmark Study / J.S. Wallerstein, J.M. Lewis. NY, 2000. - P. 248-265.

\section{Proskurniak Olga Petrivna}

Candidate of Psychological Sciences, Associate Professor at the Department of Psychology of the Chernivtsi National University named after Yuriy Fedkovych, Chernivtsi (Ukraine)

\section{Papushak Natalia Lubomyrivna}

Master student at the Department of Psychology of the Chernivtsi National University named after Yuriy Fedkovych, Chernivtsi (Ukraine)

\section{PSYCHOLOGICAL FACTORS INFLUENCING THE SUCCESSFULNESS OF MARRIAGE}

\section{ABSTRACT}

The successfulness of marriage is a complex integral indicator which contains the assessment of marriage relationships from the point of view of: a) society and the inclusion of the family to the social system (social component); b) harmonious and functional life of the family in the process of its settling and development (family-system component); c) most complete achievement of each spouse's personal potential, building mature interpersonal communication between them (existential- humanistic component).

Successful marriage expects everyday, emotional and sexual adaptation, which is followed by a certain level of inner understanding of marriage partners, while preserving and acknowledging individual needs of both partners.

Two groups of factors for successful marriage are distinguished: the ones, which had existed before the wedding; and those, which appeared during the married period. The first group of factors is the psychological basis of marriage. It combines such aspects, as parentage (a bit similar to the notion "family script" suggested by E.Bern), personal features, and motives for getting married.

The second group consists of ethicalemotional and psychophysiolgical relationships between spouses, unity of opinions on children's upbringing, distribution of household duties, free time activities, relationships with in-laws and friends.

Adaptational processes in psychological, sexual, spiritual spheres and intimacy (which includes liking, gratitude and erotic attraction), are viewed as homeostabilizing values. The mechanism of development and transformation of marital relationships is the marital autonomy, which is expressed in the fact, thatthe interests of spouses are wider than family's; and the needs, as well as communication circles exceed the limits of marriage.

Key words: marriage, marriage satisfaction, successfulness and stability of 
marriage.

\section{Проскурняк Ольга Петровна}

Кандидат психологических наук, дочент кафедры психологии Черновиикого национального университета имени Юрия Федьковича, г. Черновиь (Украина)

\section{Папушак Наталья Любомировна}

Магистр факультета психологии Черновицкого национального университета имени Юрия Федьковича, г. Черновиы (Украина)

\section{ПСИХОЛОГИЧЕСКИЕ ФАКТОРЫ ВЛИЯЮЩИЕ НА УСПЕШНОСТЬ БРАКА}

Аннотация. Статья посвящена исследованию понятий «удовлетворенность супружеской жизнью», «успешность и стабильность брака». Подано краткий обзор проблемы, описано феноменологию категорий в научных исследованиях, изложены теоретические и методологические подходы к изучению факторов успешности брака в целом.

Установлено, что факторами успешности брака выступает психологическая совместимость партнеров, соответствие их ролевым ожиданиям, социальнопсихологический климат в семье. Успешные семейные связи формируются при обоюдной удовлетворенности супругов, их соответствии друг другу в различных видах и областях взаимодействия внутри семьи и за еe границами.

Ключевые слова: брак, удовлетворенность супружеской жизнью, успешность и стабильность брака. 